\title{
Antibacterial Activities of Ethanolic Extract of Malva sylvestris L. Against Salmonella enterica and Escherichia coli Isolated from Diarrheic Lambs
}

\section{Yaser Nozohour*, Ghader Jalilzadeh}

Department of Internal Medicine and Clinical Pathology, Faculty of Veterinary Medicine, Urmia University, Urmia, Iran

10.30699/ijmm.15.1.121

\section{ABSTRACT}

Background and Aim: Bacterial enteritis occurred in neonatal lambs, is an economically important disease that can cause high morbidity and mortality in lambs, therefore, emergency antibacterial treatment is necessary. Malva sylvestris L. plays an important role in traditional remedies for medicinal properties. The present study aimed to evaluate the antibacterial activity of $M$. sylvestris on bacterial pathogens isolated from the stool of diarrhetic lamb.

Materials and Methods: The antibacterial activities of $M$. sylvestris hydroalcoholic extract (MSHE) were evaluated by agar diffusion and microbroth dilution methods against isolates of Salmonella enterica $(n=10)$, Escherichia coli $(n=10)$ and standard strains S. enterica PTCC 1709-CIP104115, E. coli PTCC1270.

Results \& Conclusion: The results of plant extract efficiency against clinically isolated reported as Minimum Inhibitory

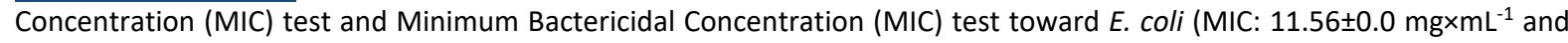

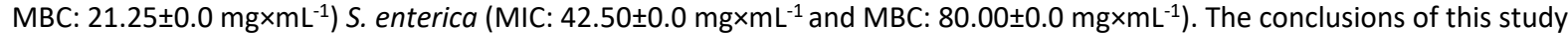
indicated that $M$. sylvestris revealed antibacterial properties and this plant could be a good candidate for the generation of new wide spectrum antibacterial agents.

Keywords: Sheep, Salmonella enterica, Escherichia coli, Anti-Bacterial agents, Plant extracts

Received: 2020/06/18; $\quad$ Accepted: 2020/11/19; Published Online: 2021/01/10

\begin{tabular}{cc} 
Corresponding Information: & $\begin{array}{l}\text { Yaser Nozohour, Department of Internal Medicine and Clinical Pathology, Faculty of Veterinary Medicine, Urmia University, } \\
\text { Urmia, Iran. Email: yasar nozohour @yahoo.com }\end{array}$ \\
\hline (c) (1) (5) & $\begin{array}{l}\text { Copyright ( }) \text { 2021, This is an original open-access article distributed under the terms of the Creative Commons Attribution-noncommercial } 4.0 \text { International License which } \\
\text { permits copy and redistribution of the material just in noncommercial usages with proper citation. }\end{array}$
\end{tabular}

Use your device to scan and read the article online

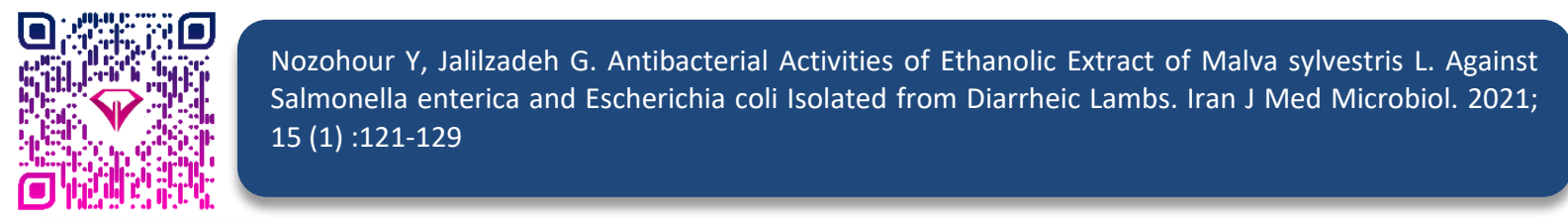

Download citation: BibTeX | RIS | EndNote | Medlars | ProCite | Reference Manager | RefWorks

Send citation to: $\otimes_{\text {Mendeley }} 2$ zotero $\underline{\underline{B}}$ RefWorks

\section{Introduction}

Diarrhea is a clinical syndrome that causes serious economic losses as it leads to high mortality, weight loss, or even late growth in various animals and even in the human people. It has appeared from enteritis, which is the inflammation of the intestinal mucosa, distinguished by abdominal pain, loose feces, an increase in stool mass, stool frequency, tendency, or stool fluidity that contain $70-95 \%$ water which leads to dehydration $(\mathbf{1}, \mathbf{2})$. Lamb diarrhea is associated with both infectious and non-infectious factors $(1,2)$. Salmonella spp. and Escherichia coli is the most common bacterial etiologic agents of lamb diarrhea during the first weeks of life $(1,3)$. Diarrhea induced by infectious organisms is the most significant cause of morbidity and mortality in ruminant neonatal in the world and it can be caused by numerous pathogens including viruses, protozoa, and bacteria $(1,3)$. Currently, there is some medication approved for the treatment of bacterial pathogens of diarrhea in the animal. Chloramphenicol, gentamicin and Enrofloxacin are used to treat bacterial-induced diarrhea in ruminants' neonates. These agents have 
several side effects, including liver and kidney failure including toxic nephrosis and hemorrhage, as well as removing the natural microflora of the digestive tract when used orally (4). Nowadays, due to the creation of microbial resistance to antibiotics, the use of other safe sources such as derived agents from plants and their compounds have been proposed as an alternative to synthetic antibiotics. Recently the results of many studies have shown that some plants interestingly can inhibit the growth of the microorganisms (5). Malva sylvestris L. an annual plant known as mallow is a genus belonging to the family Malvaceae with lobed leaves and purple flowers that bloom in late spring (6). M. sylvestris $L$. can be used as food antimicrobial agents due to their potent activity against both gram-positive and gram-negative bacteria $(7,8)$. Therefore, the present study was conducted to evaluate the antibacterial properties of $M$. sylvestris $L$. against Salmonella enterica and $E$. coli isolated from diarrheic lambs.

\section{Materials and Methods}

\section{Plant Extraction}

During summer 2018 M. sylvestris was obtained from the local market in Urmia, Iran, then the sample was authenticated by the Pharmacognosy department. Leaves were air-dried at room temperature and grounded into powder by a hammer mill. To prepare the extract, $200 \mathrm{~g}$ of powder was macerated in $70 \%$ ethanol (1:10 ratio) in a sealed container and was shaken for $24 \mathrm{hr}$ in a darkroom. The extract was filtered through Whatman No 41 filter paper and concentrated under vacuum at $40^{\circ} \mathrm{C}$ using a rotary machine, and collected powder was stored at $-80^{\circ} \mathrm{C}(9)$.

\section{Isolation and Identification of Bacteria}

In this study, 100 stool specimens collected from diarrheic Lambs were refereed to veterinary teaching hospital and clinic of Urmia University during the six months in winter and spring 2018. The strains of bacteria were identified by the use of biochemical profiles according to the directions of the manual of clinical microbiology. The assayed microorganisms used in this study were as followed: 1) Regional clinical isolates: S. enterica $(n=10)$, E. coli $(n=10)$. 2) And Reference strains: S. enterica PTCC 1709-CIP104115, E. coli PTCC1270. The standard strains were taken from Microbiology Tabriz and the Hospital of Department of Urmia University (10)

\section{Antibacterial Activity Assay}

The antibacterial activity of the extract was assessed using agar disk-diffusion, micro broth dilution (11). The minimum inhibitory concentration (MIC) and minimum bactericidal concentrations (MBC) were evaluated. Bacterial suspensions equivalent to a 0.5 McFarland turbidity were made in sterile normal saline solution from clinical and reference isolates a sterile swab dipped into the inoculum tube containing bacterial suspensions and then was cultured on the Muller-Hinton agar (Merck ${ }^{\circledR}$, Germany). Sterile filter paper discs (6 $\mathrm{mm}$ in diameter) were impregnated $M$. sylvestris extract $10 \mu \mathrm{l}\left(75 \mathrm{mg} \mathrm{mL}^{-1}\right)$ for $10-15 \mathrm{~min}$ and left to dry completely for 20-25 min, then precisely placed on the surface of previously inoculated cultures. Chloramphenicol $(30 \mu \mathrm{g})$ antibiotic discs (Merck $^{\circledR}$, Germany) were used as positive control and sterile diluent $(0.1 \%$ peptone water) was negative control for comparison of inhibition zone with the sample. Plates were incubated at $37^{\circ} \mathrm{C}$ for $24 \mathrm{~h}$ until the obvious growth of bacteria was evident in control plates. Apparent inhibition zones around discs were measured in three directions and averaged. The antibacterial activity was displayed as the diameter of the inhibition zone produced by extract against test bacteria (12).

\section{Determination of Minimum Inhibitory Concentration (MIC) and Minimum Bactericidal Concentration (MBC)}

The broth microdilution method was conducted to determine the MIC and MBC of the extract revealed by the agar diffusion assay (13). Briefly, MIC and MBC were tested in the microplate reader, using sterile 96 wells plates. Each well was loaded with a total volume of $100 \mu$ containing Mueller-Hinton broth (MHB). Different concentrations of each extract 100, 50, 25, $12.5,6.25$ and $3.12 \mathrm{mg} \mathrm{mL}^{-1}$ was provided by serial dilution (dilution by one-half) in MHB. $100 \mu \mathrm{l}$ of inoculums contains approximately $5 \times 10^{5} \mathrm{CFU} / \mathrm{mL}$ of test bacteria were added to each well. Negative controls contained a non-inoculated medium with extract samples and positive controls wells were prepared with inoculated culture medium with no extracts [13]. Resazurin powder (11) (Sigma-Aldrich) was diluted in distilled water to a final concentration of $1 \mathrm{mg} / \mathrm{ml}$ and $10 \mu \mathrm{L}$ was added to all wells (13). Microplates were incubated at $37^{\circ} \mathrm{C}$ for $24 \mathrm{hr}$. The MIC was determined by observing the lowest concentration of extract which would inhibit the apparent growth of bacteria. For determination of minimum bactericidal concentrations (MBC), $20 \mu \mathrm{L}$ of the suspension of well before MIC of the extract were cultured on $\mathrm{BHI}$ agar using the spread plate technique. After 24 hours of incubation at $37^{\circ} \mathrm{C}$, the $\mathrm{MBC}$ was evaluated by calculating the number of bacterial colonies (13). 


\section{Results and Discussion}

The antimicrobial characteristics of the $M$. sylvestris against clinically isolates of S. enterica and E. coli were determined and presented as MICs and MBCs values. $M$. sylvestris extract showed the highest effect against clinical isolate of $E$. coli (MIC: $11.56 \pm 0.0 \mathrm{mg} \mathrm{mL}-1$ and MBC: $21.25 \pm 0.0 \mathrm{mg} \mathrm{mL}-1$ ). Details presented in Tables 1 and 2 . Bacterial enteritis in lambs is the most common and important disease that can cause severe economic loss in the sheep production industry. Lambs are at greatest risk of diarrhea during the first month of the neonatal period, although the incidence of diarrhea declines with age (14). Enteropathogens have a high level of resistance to commonly used antibiotics therefore resistance to new drugs develops quite fast. Diarrheal diseases are greatly more common among lambs group and the search for new agents with antibacterial activity against enteropathogens has a public health priority $(\mathbf{1}, \mathbf{2})$. New antimicrobials derived from medicinal plants resulting in recovery without side effects. This is very important since a major problem with antibiotics is a common failure to achieve successful treatment, which in turn favors the selection of resistant bacterial strains. With the focus of research on the undesired effects of chemical drugs, the use of herbal medicines has been re-considered (16). Most of the plant extracts have antimicrobial activity, which is mainly associated with their phenolic compounds. The higher amount of phenolic material in the plant extracts appears more antimicrobial activity (16). In a study by 17. Mohajerfar that was done on 10 different species of bacteria, it is shown that the methanol extract of $M$. sylvestris had an antibacterial effect on B. pumilus (17). The results of another study showed that the extract of $M$. rotundifolio had a strong inhibiting effect on S. aureus, $P$. aeruginosa, B. subtilis, $K$. pneumoniae, and $E$. coli (18). It was revealed that methanolic extracts of the flower and leaves of $M$. sylvestris show high antimicrobial activity against $S$. aureus, S. agalactiae, and E. faecalis (22). DostMohamadi et al. (2012) mentioned that the ethanolic extracts of Malva neglecta with nanosilver particles had an inhibitory effect on $S$. aureus and $S$. typhimurium which were consistent with our findings (19). Elvin-lewis et al. (2009) demonstrated the antibacterial effect of $M$. neglecta on the Nocardia strain (15). The result of this study confirmed that the M. sylvestris has an antibacterial effect against Salmonella enterica and E.coli. According to the results presented here and from previous research, $M$. sylvestris potentially has a wide-spectrum antimicrobial effect. Studies are needed to characterize the accurate and precise mechanisms of $M$. sylvestris ingredients and to study its toxicity to further define the potential therapeutic benefit of it or the risk that accompanies oral administration of this plant extract respectively.

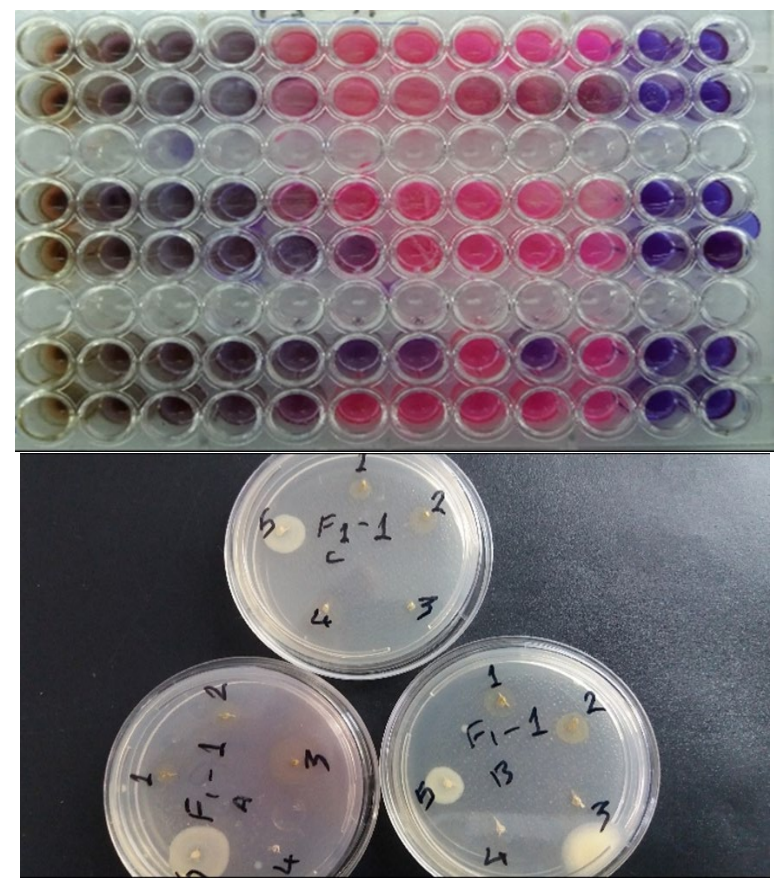

Figure 1. Microplates and plate showing the MICs and MBC: Columns 1-10 (contain serial dilutions of extracts), columns 11 (growth control wells), columns 12 (sterility control wells): Purple color (lack of bacterial growth) and Pink color (bacterial growth).

Table 1. MICs and MBCs of M. sylvestris extract against standard and clinically isolated bacteria

\begin{tabular}{|ccc|}
\hline Bacteria & MIC $\left(\mathrm{mg} \mathrm{mL}^{-1}\right)$ & \multicolumn{1}{c}{$\mathrm{MBC}_{\left(\mathrm{mg} \mathrm{mL}^{-1}\right)}$} \\
\hline S. enteric (1709-CIP104115) & $50 \pm 0.0$ & $100 \pm 0.0$ \\
\hline S. enteric (clinical isolate) & $42.5 \pm 0.0$ & $80 \pm 0.0$ \\
\hline E. coli (PTCC -1270) & $50 \pm 0.0$ & $100 \pm 0.0$ \\
\hline E. coli (clinical isolate) & $11.56 \pm 0.0$ & $21.25 \pm 0.0$ \\
\hline
\end{tabular}


Table 2. Diameter of inhibition zone $(\mathrm{mm})$ of $M$. sylvestris extract and antibiotic disk extracts tested against standard and clinically isolated bacteria

\begin{tabular}{|c|c|c|}
\hline Bacteria & $\begin{array}{l}\text { M. sylvestris } \\
\left(75 \mathrm{mg} \mathrm{mL}^{-1}\right)\end{array}$ & $\begin{array}{l}\text { Chloramphenicol } \\
\text { (0.03 mg/disc) }\end{array}$ \\
\hline S. enteric (1709-CIP104115) & 10.2 & 13.9 \\
\hline S. enteric (clinical isolate) & 15 & 17 \\
\hline E. coli (PTCC -1270) & 13.3 & 16 \\
\hline E. coli (clinical isolate) & 16 & 20 \\
\hline
\end{tabular}

\section{Conclusion}

The results of this study indicate that $M$. sylvestris has antibacterial properties. In particular, $M$. sylvestis can be considered as a suitable substitute for synthetic antibiotics to treat the bacterial diarrheic lambs as a cheap and available source. Certainly, more studies are needed to consider the mechanisms of antibacterial effects of $M$. sylvestris and its compounds more accurately. Therefore, taking into account the detrimental effects of antibiotics, the use of medicinal plants-based drugs can be a new horizon for controlling and controlling diarrhea pathogens especially bacteria.

\section{Acknowledgment}

We thank Hospital of Urmia and Microbiology Department of Urmia University

\section{Conflict of Interest}

All authors disclose any financial and the authors declare that there are not any potential conflicts of interest. 


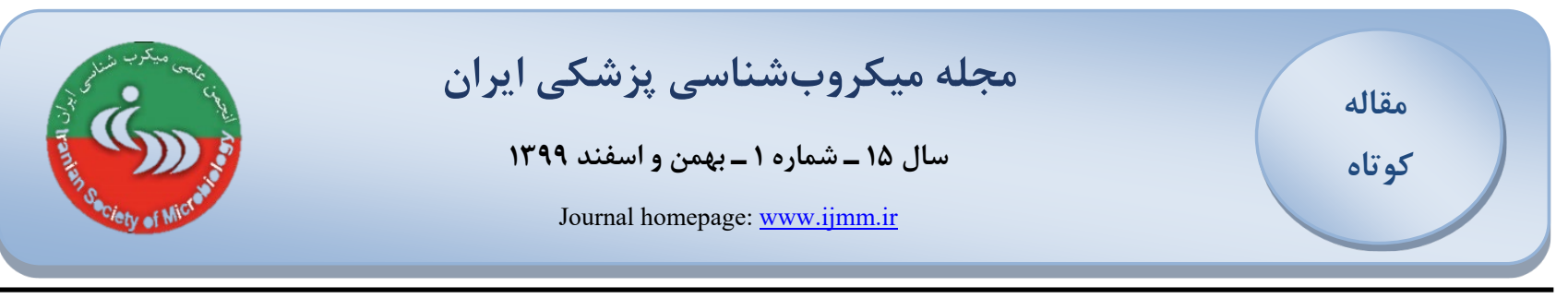

\title{
فعاليت ضد باكتريايى عصاره اتانولى كياه هنيرك بر عليه سالمونلا انتريكا و /شريشياكلى إلى

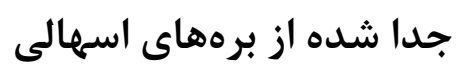

\author{
ياسر نوظهور "، قادر جليل زاده امين \\ كَروه بيمارى هاى درونى و كلنيكال ياتولوزِى،دانشكده داميزشكى، دانشعاه اروميه، اروميه، ايران
}

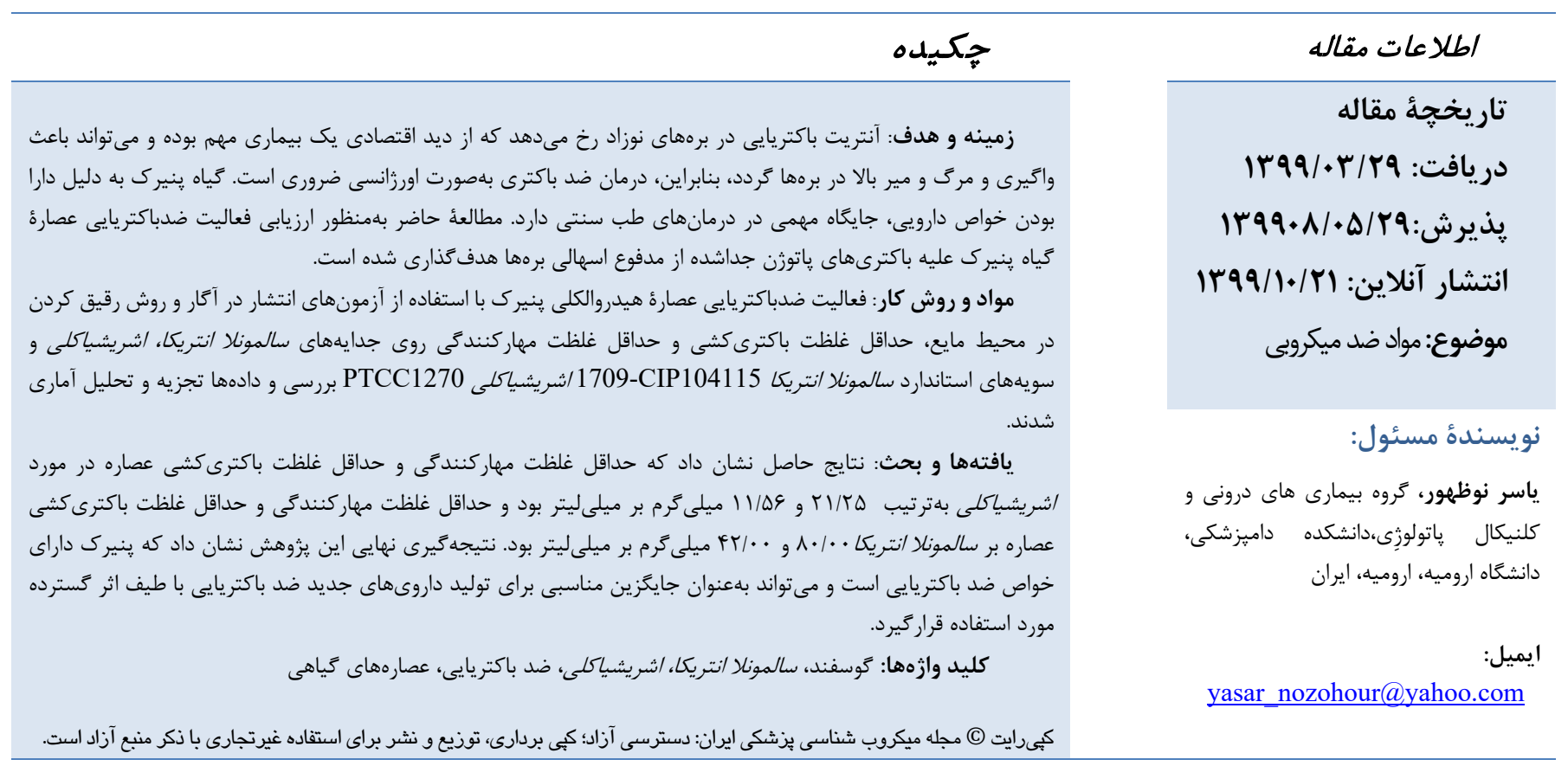

مقلمهd

حاضر، داروهايى براى درمان عوامل باكتريايى ايجاد كننده اسهال در حيوانات وجود دارند. كلرامفنيكل، جنتامايسين و انروفلوكساسين براى براي درمان اسهال ناشى از باكترىها در نوزادان نشخواركننده استفاده مىشود. اين داروها داراى عوارض جانبى مانند نارسايىهاى كبدى و و

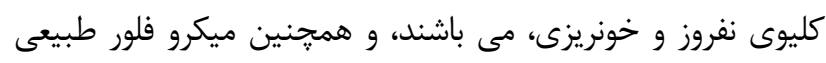

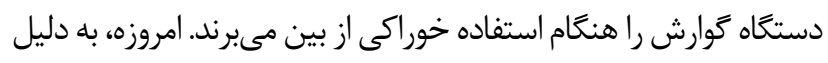

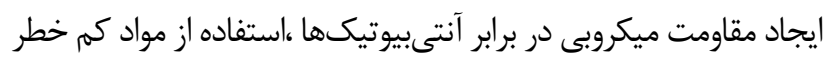

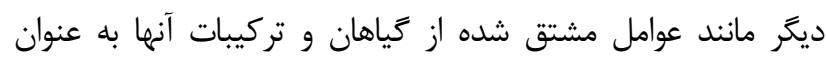
جايخزينى براى توليد آنتىبيوتيكهاى مصنوعى بيشنهراد شده است. اخيراً نتايج بسيارى از مطالعات نشان مى بدهد كه برخى از زياهان به به طرز جالب توجهى مىتوانند از رشد ميكروار كانيسمها جلوخيرى كنند مئد

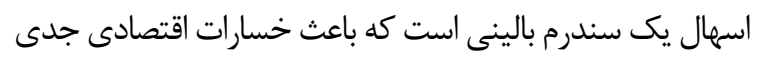
مىشود زيرا منجر به مرت و مير ، كاهش وزن يا عقب افتادكى رشد در

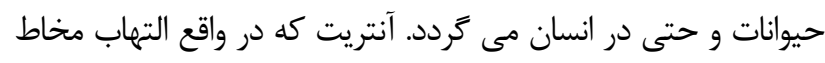
روده است و با شكم درد، مدفوع شل، افزايش مقدار و دفعات مدفوع، آبكى بودن •.V-.9 درصدى مدفوع منجر به كم آبى بدن مىشود.

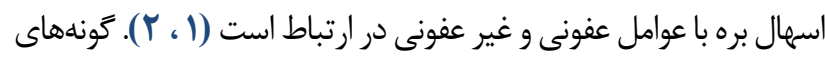

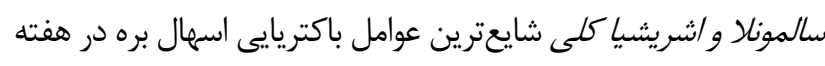
هاى اول زندكَى هستند (ا، r). اسهال ناشى از اركانيسمهاى عفونى

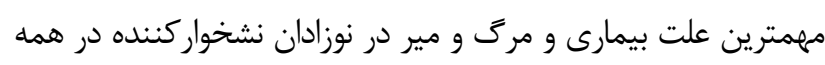
جاى جهان است و مىتواند توسط عوامل بيمارىزاى بى شمارى از جمله ويروس ها، تك ياختهها و باكترىها ايجاد شود (ا، ب). در حال 
شده در آكار مولر -هينتون (مركى ، آلمان) كشت داده شد. روى هر كدام

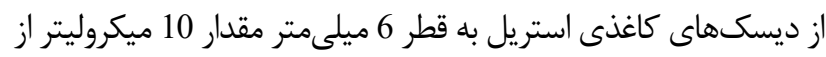

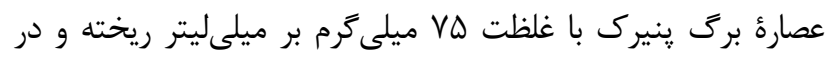

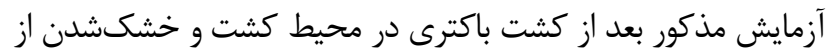

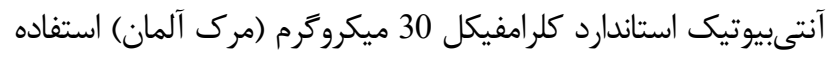
شد. يُتها بهمدت 24 ساعت در دماى مناسب كرمخانه كذاشته شد.

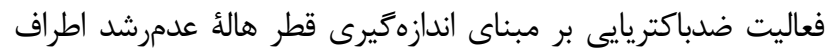
ديسكها بر حسب ميلىمتر انجام كرفت (r) (I).

\section{تعيين حداقل غلظت مهاركنندكى و حداقل غلظت} باكترى كشى تعين

براى بررسى اثر مهاركنندكى و باكترى كشى عصاره از روش

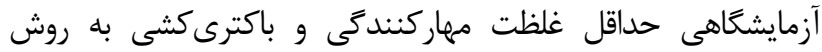
رقيقسازى در محيط مايع استفاده شد. بلهور خلاصه در اين روش از

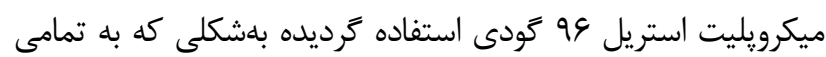

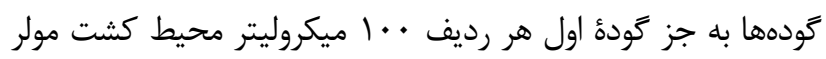

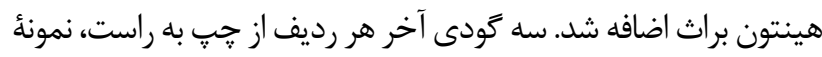

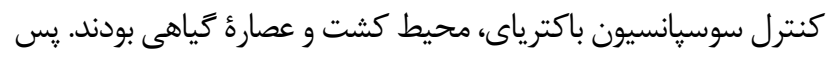

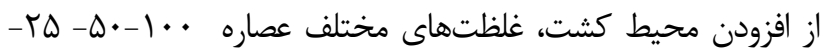
ا

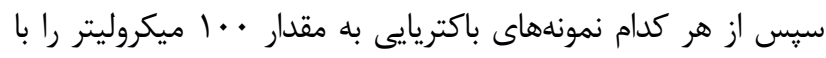

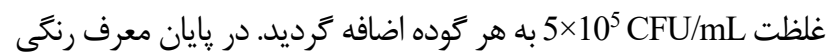
رزازورين (II) اميلى ترم بر ميلىليتر به ميزان •ا ميكروليتر به تمامى

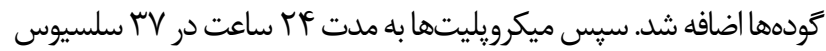

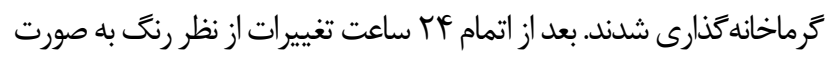
جشمى بررسى شد. براى تعيين حداقل غلظت بازدارنده رشد كمترين

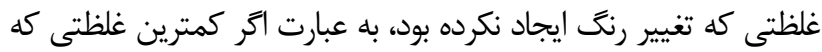

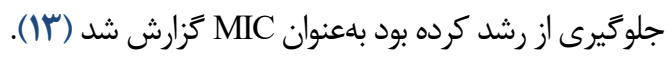

براى تعيين كمترين غلظت باكترى كشى، بعد از قرائت نتيجه

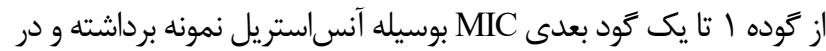

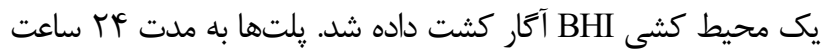

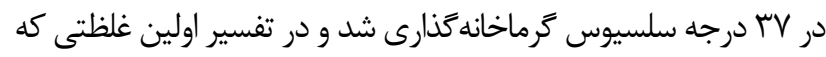
در آن هيج رشدى ديده نشده به ستون MBC ثبت شد

\section{نتايج و بحث}

اثر ضد ميكروبى ينيرك در برابر جدايههاى بالينى سالمونلا انتريكا و /شريشياكلى به روش MIC و MBC تعيين شد. عصاره ينيرك بيشترين اثر را در برابر جداسازى بالينى /شريشيا كلى نشان داد
(ه). ينيرك گياه يك ساله است از خانواده مالواسه كه در اواخر بهار گل

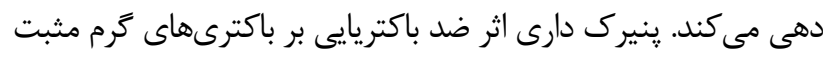

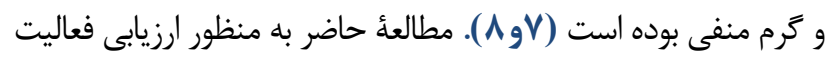

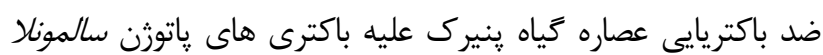

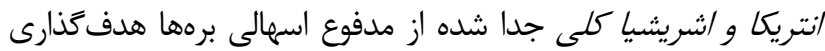

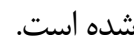

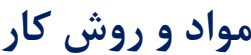

\section{تهيئ عصاره برك ينيرك}

در تابستان 11 • ب كَياه ينيرك از بازار محلى اروميه خريدارى شده و سيس نمونه توسط بخش فارماكو كنوزى تاييد گرديد. برك آنها در

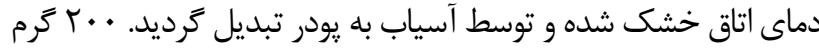
نمونهُ يودرشده برك بنيرك با حلال اتانول •V درصد (1: • (1) كاملاً

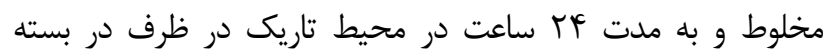
خيسانده شدند. براى تسريع عمل عصارهزيرى، ظرف حاوى يودر زياهى و حلال روى دستكاه لرزاننده قرارداده شد. بعد از اتمام عمليات

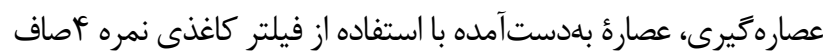

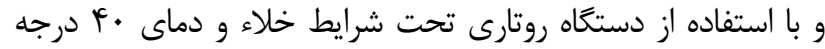

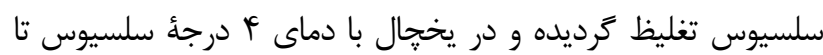

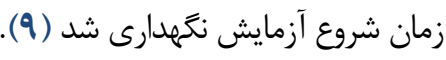

\section{جداسازى و شناسايى باكترى ها}

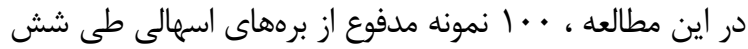

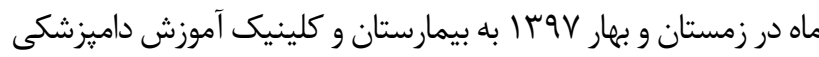
ارجاع شده بود، جمعآورى كرديد. سويه هاى باكترى با استفاده از بـاز

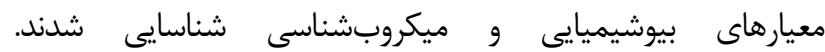
ميكرواركانيسمهاى مورد استفاده در اين مطالعه به شرح زير بودند:

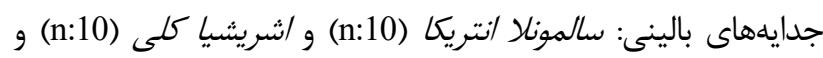

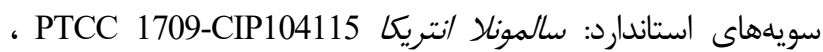

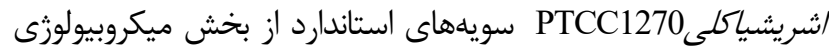

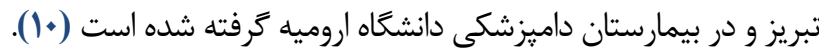
فعاليت ضد باكتريايى عصاره با استفاده از آزمونهاى انتشار در

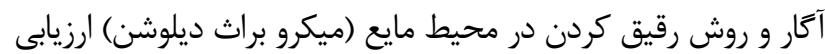

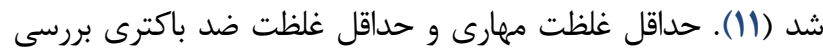

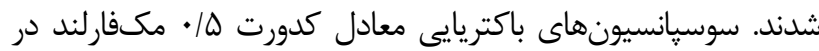
محلول نرمال نمكى استريل از جداشدهاى بالينى و مرجع تهيه كَرديد؛ سيس يك سواب استريل آغشته به سوسيانسيونهاى باكتريايى آماده 
كردند كه عصارههاى اتانولى گونهاى از ينيرك همراه با نانو ذرات نقره اثر مهارى بر /ستافيلوكوكوس /ورئوس و سالمونلا تيفى موريوم

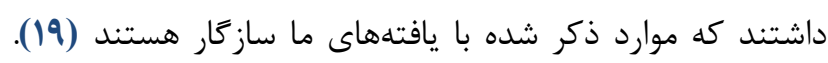

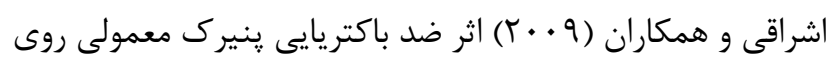

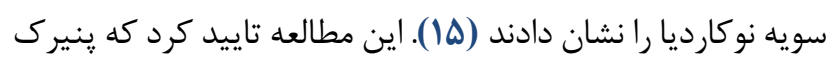

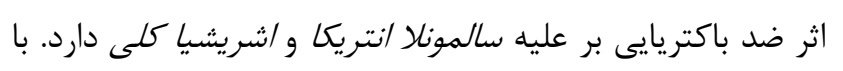

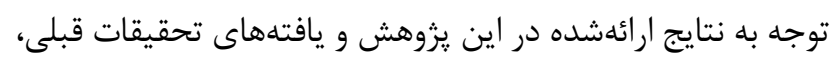

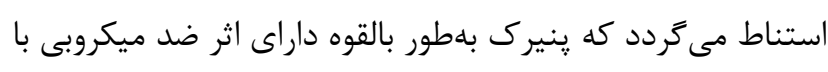

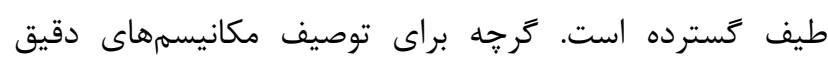

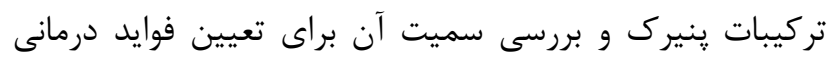

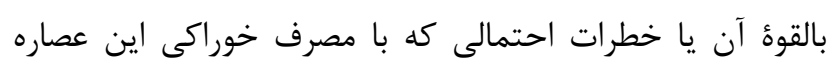

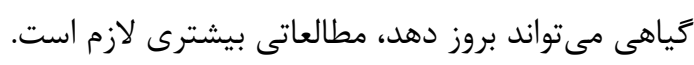

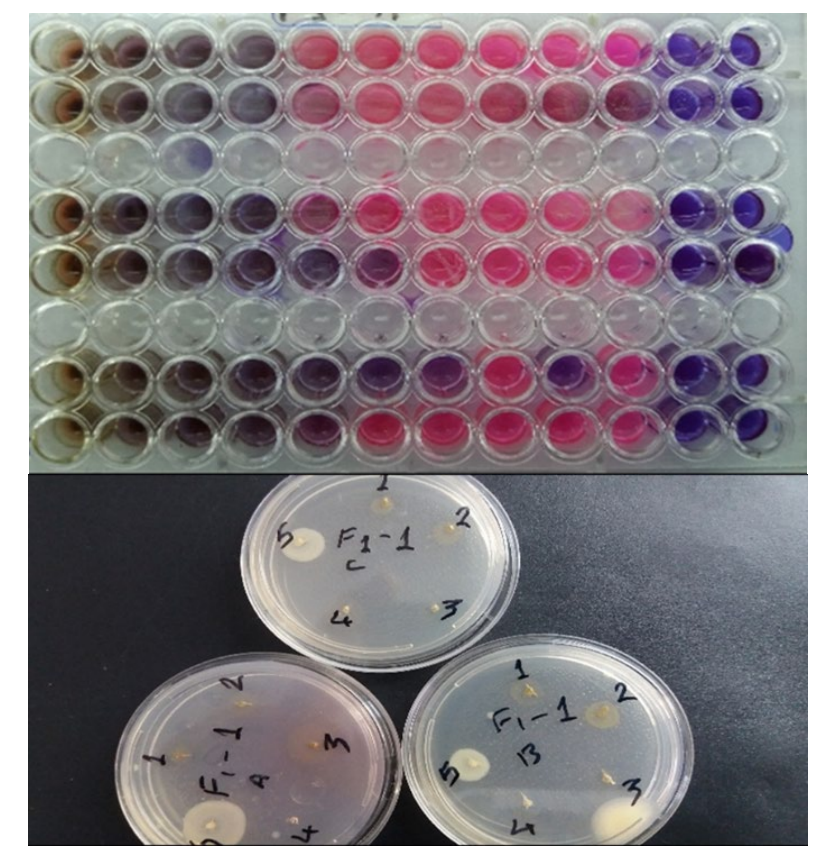

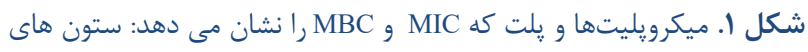

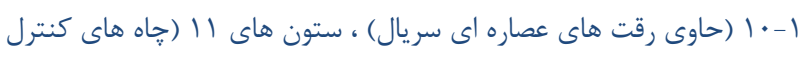

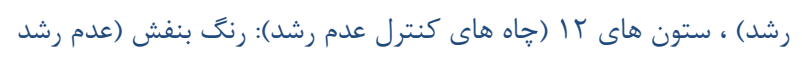

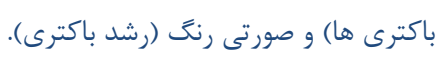

(حداقل غلظت مهار كنند

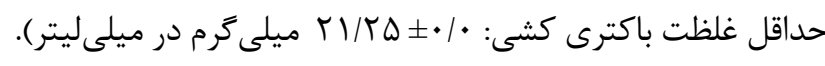

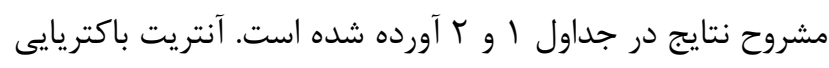

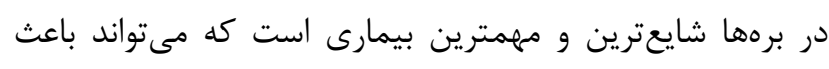

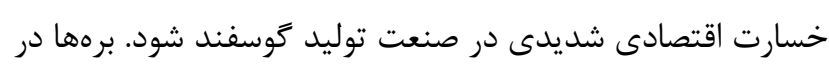

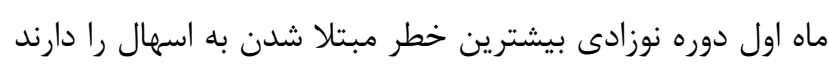

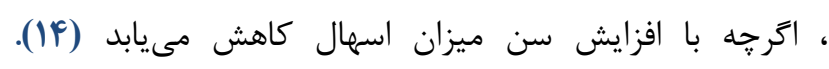

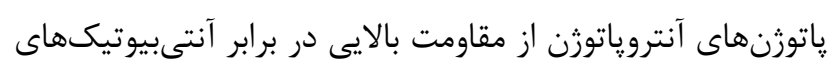

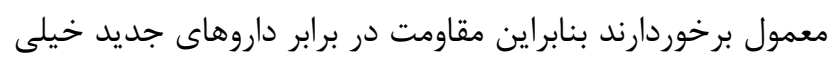

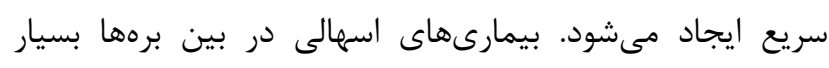

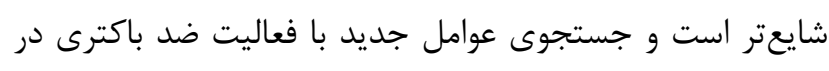

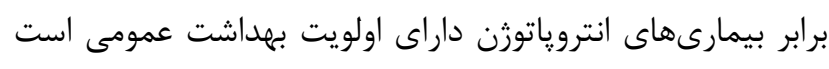

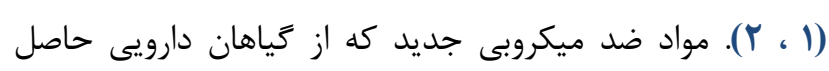

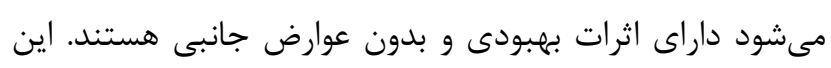

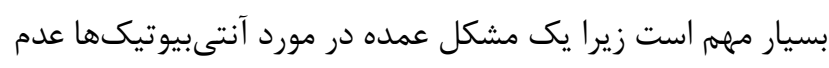

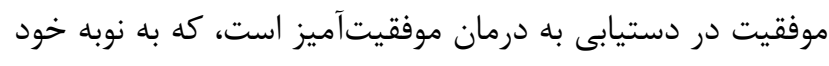

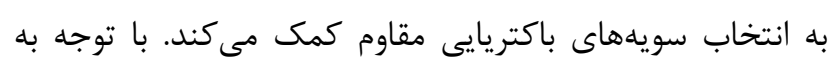

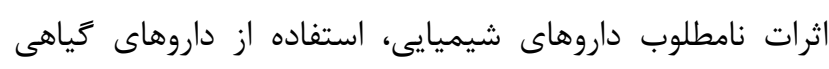

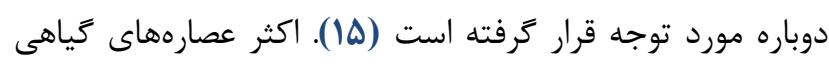
داراى فعاليت ضد ميكروبى هستند كه عمدتا با تركيبات فنلى آنها

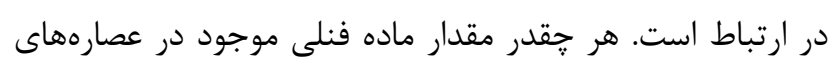

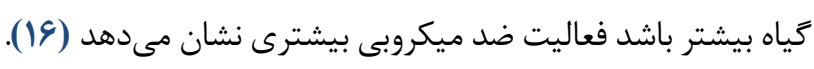

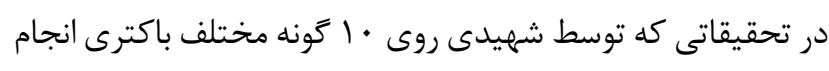

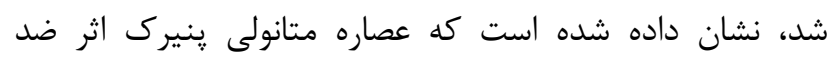

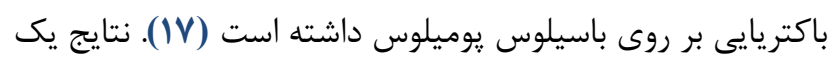

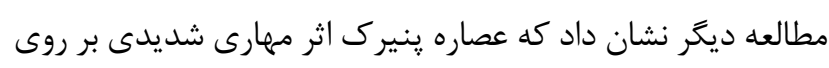

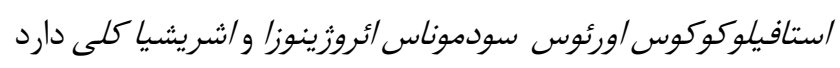

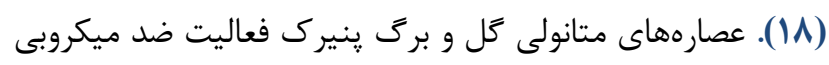

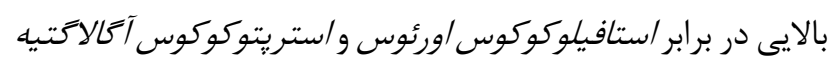

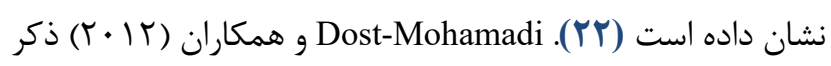

جدول ا. حداقل غلظت باكترى كشى و حداقل غلظت مهار كنندَى عصاره ينيرك بر باكترى هاى بالينى و استاندارد

\begin{tabular}{|c|c|c|}
\hline حداقل غلظت مهاركنندكَى & حداقل غلظت باكترى كشى & سويه باكترى \\
\hline$\cdot / \cdot \pm \Delta$ & $\cdot / \cdot \pm 1 \cdot \cdot$ & سالمونلا انتريكا استاندارد \\
\hline$\cdot 1 \cdot \pm F T / \Delta$ & $\cdot / \cdot \pm \wedge$ & سالمونلا انتريكا بالينى \\
\hline$\cdot / \cdot \pm \Delta$ & $\cdot / \cdot \pm 1 \cdot$ & اشريشياكلى استاندارد \\
\hline$\cdot / \cdot \pm 11 / \Delta 9$ & $\cdot / \cdot \pm r l / r \Delta$ & / شريشياكلى بالينى \\
\hline
\end{tabular}




$$
\text { جدول r. قطر هاله عدم رشد ايجاد شده توسط عصاره ينير و و آنتىبيوتيك }
$$

\begin{tabular}{|c|c|c|}
\hline كلرامفنيكول (ميلى متر) & عصاره هنيرك (ميلى متر) & سويه باكترى \\
\hline $1 \% / 9$ & $1 \cdot / r$ & سالمونلا انتريكا استاندارد \\
\hline iv & 10 & سالمونلا /نتريكا بالينى \\
\hline 19 & $1 \% / r$ & اشريشياكلى استاندارد \\
\hline$r$ r. & 19 & / شريشياكلى بالينى \\
\hline
\end{tabular}

$$
\begin{aligned}
& \text { مىتواند افق جديدى براى كنترل و درمان عوامل بيمارىزاى }
\end{aligned}
$$

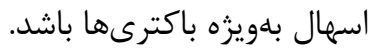

$$
\begin{aligned}
& \text { سياسگَزارى } \\
& \text { بدين وسيله از بيمارستان داميزشكى دانشعاه اروميه تشكر و }
\end{aligned}
$$

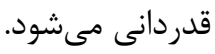

$$
\begin{aligned}
& \text { تعارض در منافع }
\end{aligned}
$$

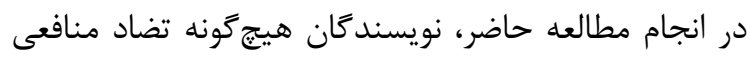

نداشتهاند.

\section{Referance}

1. SmithPalmer A, Stewart W, Mather H, Greig A, Cowden A, Cowden J, Reilly W. Epidemiology of S. enterica and Typhimurium in animals and people in Scotland between 1990 and 2001. Vet Rec. 2003; 153(17): 517-20. [DOI:10.1136/vr.153.17.517] [PMID]

2. Buxton A, Fraser G. Animal Microbiology. Oxford, London, UK: Blackwell Scientific Publications. 1977 Jan 1; 1: 94-102.

3. AwadMasalmeh M. Virulence genes of verotoxin producing non-157 E. coli strains isolated from healthy small ruminants and cattle. Wiener Tierarztliche Monatsschrift. 2004 Jan 1; 91 (2): 4755.

4. Ghamarian A. compendium of data sheets for veterinary products. 2005-2006.

5. KollanoorJohny A, Darre M, Hoagland T, Schreiber D, Donoghue A, Donoghue D, Venkitanarayanan K. Antibacterial effect of trans- cinnamaldehyde on Salmonella Enteritidis and Campylobacter jejuni in chicken drinking water. J Appl Poult Res. 2008 Des 1; 17 (4): 490-497. [DOI:10.3382/japr.2008-00051]

6. Zhenyu W, Qian Y. Study on physico-chemical properties of the pigment in flowers of mallow. J Chem Indus Forest Produc. 2003 Sep 9; 23(3): 1024.
7. Valnet J. Phytotherapy, treatment of disease by plants. Translated to Persian by: Emami A, ShamsArdekani MR, Nekoei-naeini N. Tehran. Rahe-kamal Pub. 2002; 61-358.

8. Shale T, Stirk W, van Staden J. Variation in antibacterial and anti-inflammatory activity of different growth forms of Malva parviflora and evidence for synergism of the anti-inflammatory compounds. J Ethnopharmacol. 2005 Jan 4; 96(12):325-30. [DOI:10.1016/j.jep.2004.09.032] [PMID]

9. Gavanji S, Larki B, Bakhtari A. The effect of extract of Punica granatum var. pleniflora for treatment of minor recurrent aphthous stomatitis. Integr Med Res. 2014 Jun 1; 3(2): 83-90. [DOI:10.1016/j.imr.2014.03.001] [PMID] [PMCID]

10. Jorgensen J, Turnidge J. Susceptibility test methods: dilution and disk diffusion methods. In: Jorgensen J, Pfaller M, Carroll K, editors. Manual of Clinical Microbiology. 11th ed. Washington, DC: American Society of Microbiology. 2015. 1253-1273. [DOI:10.1128/9781555817381.ch71]

11. Nozohour Y, Golmohammadi R, Mirnejad R, Fartashvand M. Antibacterial activity of pomegranate (punicagranatum 1.) seed and peel alcoholic extracts on staphylococcus aureus and pseudomonas aeruginosa isolated from health centers. J Appl Biotechnol Rep. 2018 Mar 30; 5(1):32-36. [DOI:10.29252/JABR.01.01.06] 
12. Andrews J. Determination of minimum inhibitory concentrations. J Antimicrob Chemother. $2001 \mathrm{Jul} 48$ (1):5-16. [DOI:10.1093/jac/48.suppl_1.5] [PMID]

13. Hajifattahi F, Moravej-Salehi E, Taheri M, Mahboubi A, Kamalinejad M. Antibacterial effect of hydroalcoholic extract of Punica granatum Linn. Petal on common oral microorganisms. Int $\mathbf{J}$ Biomater. 2016 Jan 14:1-6 [DOI:10.1155/2016/8098943] [PMID] [PMCID]

14. Garcia A, Ruiz-Santa-Quiteria J, Orden J, Cid D, Sanz R, Gómez-Bautista M, et al. Rotavirus and concurrent infections with other enteropathogens in neonatal diarrheic dairy calves in Spain. Comp Immunol Microbiol Infect Dis. 2000 Jul 23 (3):17583. [DOI:10.1016/S0147-9571(99)00071-5]

15. Elvin-lewis M. should we be concerned about herbal remedies. J Ethnopharmacol. 2001 May 75 (2): 14164. [DOI:10.1016/S0378-8741(00)00394-9]

16. Mashak Z, Moradi B, Moradi B. The Combined Effect of ZatariamultifloraBoiss. andCinnamomumzeylanicumNees. Essential Oil on the Growth of Bacillus cereus in a Food Model System. J Med Plants 2012; 11(42): 62-73.

17. Mohajerfar T, Hosseinzadeh A, AkhondzadehBasti A, Khanjari A, Misaghi A, GandomiNasrabadi H. Determination of minimum inhibitory concentration (MIC) of Zatariamultiflora Boiss. Essential oil and Lysozim on L. monocytogenes. J Med Plants. 2012; 11(44):70-77.

18. Dulger B, Gonuz A. Antimicrobial activity of certain plants used in Turkish traditional medicine. Asian $\mathrm{J}$ Plant Sci. 2004; 3(1): 104-7. [DOI:10.3923/ajps.2004.104.107]

19. Dost-Mohamadi M. Nasiri-Semnani SH, Shapouri R, Alizadeh H, Abdo-lahzade P. Evaluation of antibacterial effects of aquatic and etha-nolic extracts of Malva neglecta \& Silver nanoparticle on Staphylococus aureus and Salmonella typhimurium in In vivo and In vitro. J Zabol U Med Sci Health Serv. 2012; 4(1): 99-111.

20. Zareii B, Seyfi, Movahedi R, Cheraghi J, Ebrahimi S. Antibacte-rial effects of plant extracts of Alcea digitata L., Satureja bachtiari-ca L. And Ferula go angulate L. J Babul University Med Sci. 2014; 16(1):31-7.

21. Razavi S, Zarrini G, Molavi G, Ghasemi G. Bioactivity of Malva sylvestris L. a medicinal plant from Iran. Iran J Basic Med Sci. 2011 nove; 14 (6):574-9. 